\title{
Genome analysis of Salmonella strains isolated from imported frozen fish in Burkina Faso
}

Assèta Kagambèga ${ }^{1,2,3^{*}}$, Salifou Belem², Elizabeth A. McMillan', Lari M. Hiott ${ }^{1}$, Hazem Ramadan ${ }^{1,4}$, Daniel K. Soro², Poonam Sharma', Sushim K. Gupta', Nicolas Barro², Charlene R. Jackson¹ and Jonathan G. Frye ${ }^{1}$

\begin{abstract}
Purpose: Fish is an excellent source of protein and vitamins for humans, but improperly handled, fish can expose consumers to pathogenic bacteria. This study was aimed to isolate and characterize the genomes of Salmonella strains isolated from imported fish sold in the open market in Ouagadougou.

Methods: One hundred and fifty-nine fish were collected from open markets and were cultured for Salmonella. Antimicrobial susceptibility was determined by broth microdilution. Whole-genome sequencing was done to further study antibiotic resistance genes, plasmid replicons, and MSLT types. Serotyping was done using SeqSero 2.

Result: Out of the 159 fish samples analyzed, 30 (18.9\%) were found to be contaminated with Salmonella. Among the isolated Salmonella strains, six different serotypes, Nima, Liverpool, Kokomlemle, Teshie, Derby, and Tennessee, were found using SeqSero2. Salmonella Tennessee was the predominant serotype. All the isolates possessed at least one resistance gene. The aac6-laa aminoglycoside resistance gene was the most prevalent gene found in the strains. The gene fosA7 was detected in three strains. All the S. Nima isolates were of Multilocus Sequence Type (MLST) 8086, S. Teshie isolate was ST 530; Liverpool was ST 1959; Derby was ST 7880; Kokomlemle was ST 2696. The Tennessee isolates gave two different STs including ST 8395 and 8398.

Conclusion: The presented results highlight the prevalence of Salmonella on imported fish purchased from the open markets. More attention should be paid regarding fish selling conditions in the country to prevent the potential health risk for consumers.
\end{abstract}

Keywords: Salmonella, Antimicrobial resistance, Serotype, Fish

\section{Introduction}

Burkina Faso is a landlocked tropical country located in sub-Saharan Africa. This country is characterized by a dry season from October-May with hot temperature $\left(35-45{ }^{\circ} \mathrm{C}\right)$ and a short rainy season (June-September). In recent years, fish consumption

\footnotetext{
*Correspondence: kagambega.asseta@gmail.com; kagamas2007@yahoo.fr 'Bacterial Epidemiology and Antimicrobial Resistance Research Unit, U.S. National Poultry Research Center, USDA, ARS, Athens, Georgia, USA 2Laboratoire de Biologie Moléculaire, d'épidémiologie et de surveillance des bactéries et virus transmissibles par les aliments (LaBESTA)/Ecole Doctorale Sciences et Technologies (EDST), Université Joseph KI-ZERBO, Ouagadougou, Burkina Faso

Full list of author information is available at the end of the article
}

has increased exponentially in this country with more than $96 \%$ of commercially sold fish imported from another country (Ministry of economic and sustainable development, Burkina Faso. Statistique douanieres 2015). Fish is an important source of essential amino acids and good fatty acids for humans, but fish can be contaminated by pathogenic bacteria that pose a high risk for consumer's health (Yan et al. 2010; Nwiyi and Onyeabor 2012). These pathogenic bacteria can contaminate ready to eat fish product through cross-contamination during fish processing (KrisEtherton et al. 2002).

(c) The Author(s). 2021 Open Access This article is licensed under a Creative Commons Attribution 4.0 International License, which permits use, sharing, adaptation, distribution and reproduction in any medium or format, as long as you give appropriate credit to the original author(s) and the source, provide a link to the Creative Commons licence, and indicate if changes were made. The images or other third party material in this article are included in the article's Creative Commons licence, unless indicated otherwise in a credit line to the material. If material is not included in the article's Creative Commons licence and your intended use is not permitted by statutory regulation or exceeds the permitted use, you will need to obtain permission directly from the copyright holder. To view a copy of this licence, visit http://creativecommons.org/licenses/by/4.0/. 
Salmonella is a gram-negative foodborne pathogen and has been implicated in fish outbreaks worldwide (Barrett et al. 2017; Amagliani et al. 2012). More than 2500 serotypes of Salmonella have been designated based on the $\mathrm{O}$ and $\mathrm{H}$ surface antigens (Issenhuth-Jeanjean et al. 2014). Several serotypes, including Enteritidis and Typhimurium, have been implicated in outbreaks associated with seafood sources, though data from Africa is limited (Amagliani et al. 2012).

Currently, the use of antibiotics in aquaculture practices as growth promoters or for treatment and prevention of fish diseases is increasing the risk of development of antibiotic resistant bacteria among the microbiome of fish gut and/or fishing water (Miranda et al. 2018). Many studies have shown widespread transmission of antibiotic-resistant bacteria of the fish or aquatic environment to humans (Gonzalez-Escalona et al. 2005; Sørum 2006).

According to the Centers for Disease Control and Prevention $(\mathrm{CDC})$, antibiotic-resistant infection is responsible for 25,000 annual deaths in the European Union and 23,000 annual deaths in the USA (Center for Disease Control and Prevention (CDC) 2019). The World Health Organization (WHO) reported that the burden of food-borne disease is similar to the burden of malaria, tuberculosis, and even HIV/AIDS and is disproportionately borne by the least developed countries and by children (World Health Organization (WHO) 2015). Since imported fish is widely consumed in Burkina Faso, it is important to know the microbiological quality of these fish. Therefore, the present study aims to understand the epidemiology and antibiotic resistance of Salmonella strains isolated from fish using whole-genome sequencing and phenotypic methods.

\section{Materials and methods Sampling}

Imported fish samples were purchased from different open markets. All fish samples during collection were first placed in sterile polypropylene bags, then placed in polystyrene boxes containing crushed ice and stored at 4 ${ }^{\circ} \mathrm{C}$ during transportation. The samples were transported to the laboratory and processed on the same day for the presence of Salmonella spp.

\section{Bacteriological analysis}

Salmonella strains were isolated from fish samples following the methodologies described in the International Organization for Standardization 6579-2017 (International Organization for Standardization (ISO) 6579-1 2017). The fish samples were gently removed from coolers and processed using aseptic conditions. The gills, intestines, and skin were removed using sterile knives. About $10 \mathrm{~g}$ of samples (fish gills, intestines, and skin) were placed into a stomacher bag containing $90 \mathrm{~mL}$ of buffered peptone water (Liofilchem, Teramo, Italy) and homogenized (400 Circulator, Seward, London, UK) for $1 \mathrm{~min}$, then incubated for $24 \mathrm{~h}$ at $37^{\circ} \mathrm{C}$. From this nonselective pre-enrichment, $0.1 \mathrm{~mL}$ were transferred into $10 \mathrm{~mL}$ of Rappaport-Vassiliadis broth (Oxoid, Basingstoke, England) and incubated for $24 \mathrm{~h}$ at $42{ }^{\circ} \mathrm{C}$. A loopful from the selective enrichment broth was streaked onto XLD (Oxoid, Basingstoke, England) agar and incubated for $24 \mathrm{~h}$ at $37^{\circ} \mathrm{C}$. Suspected colonies on selective agar plates were purified and bio-typed by using biochemical tests and API 20E strips (BioMerieux, Marcy l'Etoile, France).

Confirmed colonies were sent to the United States Department of Agriculture, Agricultural Research Service, Bacterial Epidemiology and Antimicrobial Resistance Research Unit for future analysis.

\section{Antimicrobial susceptibility testing}

The isolates were streaked onto Tryptic Soy Agar (TSA) with 5\% Sheep blood (BA), (Fisher Scientific, USA) plates and incubated for $24 \mathrm{~h}$ at $37{ }^{\circ} \mathrm{C}$, and one colony from each plate was streaked onto a second BA2 plate for another $24 \mathrm{~h}$ at $37{ }^{\circ} \mathrm{C}$. Minimum inhibitory concentrations (MIC, $\mu \mathrm{g} / \mathrm{mL}$ ) of all Salmonella isolates were determined by broth-microdilution using the Sensititre ${ }^{\mathrm{\tau M}}$ semi-automated antimicrobial susceptibility system (TREK Diagnostic Systems Inc., Cleveland, OH, USA) and the Sensititre ${ }^{\mathrm{TM}}$ Gram-Negative plate format, GN4F, (ThermoFisher Scientific, USA), according to manufacturer's directions. MICs of the isolates for 24 antimicrobials were determined using colonies from the BA2 plates, and each isolate was classified as resistant, intermediate, or susceptible to the antimicrobials tested using the breakpoints set by Clinical and Laboratory Standards Institute (CLSI) (2016). Antimicrobials used breakpoints were as follows: Amikacin $\left(\geq 64 \mu \mathrm{g} \mathrm{mL}{ }^{-1}\right)$; Piperacillin/ tazobactam ( $\left.\geq 128 / 4 \mu \mathrm{g} \mathrm{mL} \mathrm{m}^{-1}\right)$; Tigecycline $(\geq 1 \mu \mathrm{g}$ $\left.\mathrm{mL}^{-1}\right)$; Ticarcillin/clavulanic acid $\left(\geq 128 / 2 \mu \mathrm{g} \mathrm{mL} \mathrm{m}^{-1}\right)$; Levofloxacin $\left(\geq 2 \mu \mathrm{g} \mathrm{mL} \mathrm{m}^{-1}\right)$; Nitrofurantoin $(\geq 128 \mu \mathrm{g}$ $\left.\mathrm{mL}^{-1}\right)$; Tetracycline $\left(\geq 16 \mu \mathrm{g} \mathrm{mL}^{-1}\right)$; Doripenem $(\geq 4 \mu \mathrm{g}$ $\left.\mathrm{mL}^{-1}\right)$; Minocycline $\left(\geq 16 \mu \mathrm{g} \mathrm{mL}^{-1}\right)$; Ertapenem $(\geq 2 \mu \mathrm{g}$ $\left.\mathrm{mL}^{-1}\right)$; Trimethoprim/sulfamethoxazole $(\geq 4 / 76 \mu \mathrm{g}$ $\left.\mathrm{mL}^{-1}\right)$; Imipenem $\left(\geq 4 \mu \mathrm{g} \mathrm{mL}^{-1}\right)$; Piperacillin $(\geq 128 \mu \mathrm{g}$ $\left.\mathrm{mL}^{-1}\right)$; Meropenem $\left(\geq 4 \mu \mathrm{g} \mathrm{mL}^{-1}\right)$; Gentamicin $(\geq 16 \mu \mathrm{g}$ $\left.\mathrm{mL}^{-1}\right)$; Cefazolin $\left(\geq 8 \mu \mathrm{g} \mathrm{mL}^{-1}\right)$; Tobramycin $(\geq 16 \mu \mathrm{g}$ $\left.\mathrm{mL}^{-1}\right)$; Ceftazidime $\left(\geq 16 \mu \mathrm{g} \mathrm{mL}^{-1}\right)$; Ampicillin/sulbactam $\left(\geq 32 / 16 \mu \mathrm{g} \mathrm{mL} L^{-1}\right)$; Aztreonam $\left(\geq 16 \mu \mathrm{g} \mathrm{mL} L^{-1}\right)$; Ampicillin $\left(\geq 32 \mu \mathrm{g} \mathrm{mL} L^{-1}\right)$; Cefepime $\left(\geq 32 \mu \mathrm{g} \mathrm{mL}^{-1}\right)$; Ciprofloxacin $\left(\geq 4 \mu \mathrm{g} \mathrm{mL}{ }^{-1}\right)$; Ceftriaxone $\left(\geq 4 \mu \mathrm{g} \mathrm{mL}^{-1}\right)$. For the analysis, isolates identified as intermediate were considered susceptible to the drug. Escherichia coli ATCC 25922, Pseudomonas aeruginosa ATCC 27853, Enterococcus faecalis ATCC 29212, and Staphylococcus 
aureus ATCC 29213 were controls for determination of MIC.

For each isolate, a final inoculum of $5 \times 10^{5} \mathrm{CFU} / \mathrm{ml}$ was targeted. The panels were read after $18 \mathrm{~h}$ of incubation at $35{ }^{\circ} \mathrm{C}$.

\section{Whole-genome sequencing}

Genomic DNA was isolated using the GenElute bacterial genomic DNA kit (Sigma-Aldrich, St. Louis, MO, USA) following instructions for Gram-negative bacteria. Cultures were grown in $5 \mathrm{~mL}$ of Luria-Bertani Broth, Miller (Difco ${ }^{\mathrm{Tm}}$, Becton Dickinson and Company, Sparks, MD) overnight at $37{ }^{\circ} \mathrm{C}$ with shaking. The extracted DNA quality was read using NanoDrop 2000c spectrophotometer (Thermo, Fisher Scientific, USA). DNA was stored at $-20{ }^{\circ} \mathrm{C}$ prior to library preparation.

Extracted DNA was quantified using the Qubit double-stranded DNA (dsDNA) high-sensitivity (HS) assay kit according to the manufacturer's instructions (Life Technologies, Inc., USA). The Illumina libraries were prepared using the Nextera XT DNA library preparation kit and Nextera XT index primers (Illumina, USA). The library fragment size distribution was checked using the Bioanalyzer 2100 with an Agilent HS DNA kit (Agilent Technologies, USA) and quantified using a Qubit DNA HS assay kit in a Qubit fluorometer (Thermo, Fisher Scientific, USA). The generated libraries were then sequenced using a MiSeq version 2 reagent kit with 500 or 300 cycles, depending on fragment size. The paired-end read length of $2 \times 250$ bp was used for 500 cycles and $2 \times 150 \mathrm{bp}$ for 300 cycles on the Illumina MiSeq platform. The quality metrics of the reads were performed by FastQC (http://www.bioinformatics. babraham.ac.uk/projects/fastqc/). The sequence data were assembled using the A5-miseq assembler (Coil et al. 2015), and the genome sequence was annotated via the NCBI Prokaryotic Genome Annotation Pipeline (Tatusova et al. 2016).

\section{Identification of antibiotic resistance genes, chromosomal mutations, serotypes, MLST, and plasmid from total genome sequence}

SeqSero 2 was used to determine the serotypes of Salmonella strains from genome assembly data. Using the Center for Genomic Epidemiology web tools, antibiotic resistance genes were identified using ResFinder 4.1 (Zankari et al. 2012). MLST sequence type was identified using MLST 2.0 (Larsen et al. 2012), and plasmids were detected using PlasmidFinder 2.0 (Carattoli et al. 2014).

\section{Results}

Out of the 159 fish samples analyzed, 30 (18.9\%) were found to be contaminated with Salmonella. From these 30 isolates, whole-genome sequences were generated and the assembly statistics are shown in Table 1. Among the isolated Salmonella strains, six different named serotypes, including Nima, Liverpool, Kokomlemle, Teshie, Derby, and Tennessee were found, with five having no name and only antigenic formulas. Salmonella Tennessee was the predominant serotype. All the isolates possessed at least one resistance gene. The non-functional aac6-Iaa conferring resistance to aminoglycosides was the most prevalent gene found in the strains. The gene fosA7 conferring resistance to Fosfomycin was detected in three strains. The isolates were susceptible to all drugs tested using phenotypic method. Four S. Nima isolates were identified from the 30 isolates and were all MLST Sequence Type (ST) 8086. One $S$. Teshie isolate was identified and was ST 530; three $S$. Liverpool isolates were detected and were identified as ST 1959; one $S$. Derby isolate was found and was ST 7880; one $S$. Kokomlemle was detected and was ST 2696, 15 S. Tennessee isolates were found, 14 have one of two different sequence types, ST 8395 and 8398, and one was unknown. Plasmid replicon typing results showed six isolates possessing plasmids: IncFIB and IncFII in the Teshie isolate, Col(pHAD28) and Col4401 in three Liverpool isolates, Col (MG828) in one Tennessee isolate, and IncFII(S) in one Kokomlemle (Table 2).

The whole-genome shotgun project has been deposited at GenBank under BioProject number PRJNA713376 (https://www.ncbi.nlm.nih.gov/bioproject/ PRJNA713376), and the accession numbers are listed in Table 2. The versions described in this paper are the first versions.

\section{Discussion}

The present study was initiated to determine the microbiological quality of imported and local fish consumed in the city of Ouagadougou, Burkina Faso. The prevalence of Salmonella strains was $18.9 \%$ from imported fish. This result could be explained by the fact that imported fish are exposed to several stages of handling and packaging at the farm in the country of origin, transport to Burkina Faso, reception at wholesalers, delivery to semi-wholesalers, and delivery to different retailers. All these steps undoubtedly favor the contamination by bacteria like Salmonella. However, the consumption of imported fish is very high in Burkina Faso because it is very accessible and inexpensive in all the localities of the country. In these localities, the imported fish is cut into small pieces by small traders and sold at a minimum price of 50 FCFA (about one cent of dollar). This necessitates permanent monitoring of the prevalence of germs that can affect the health of consumers as well as chemicals. The population of Burkina Faso is over $80 \%$ illiterate, which will undoubtedly lead to an increase in contamination of raw fish and the 


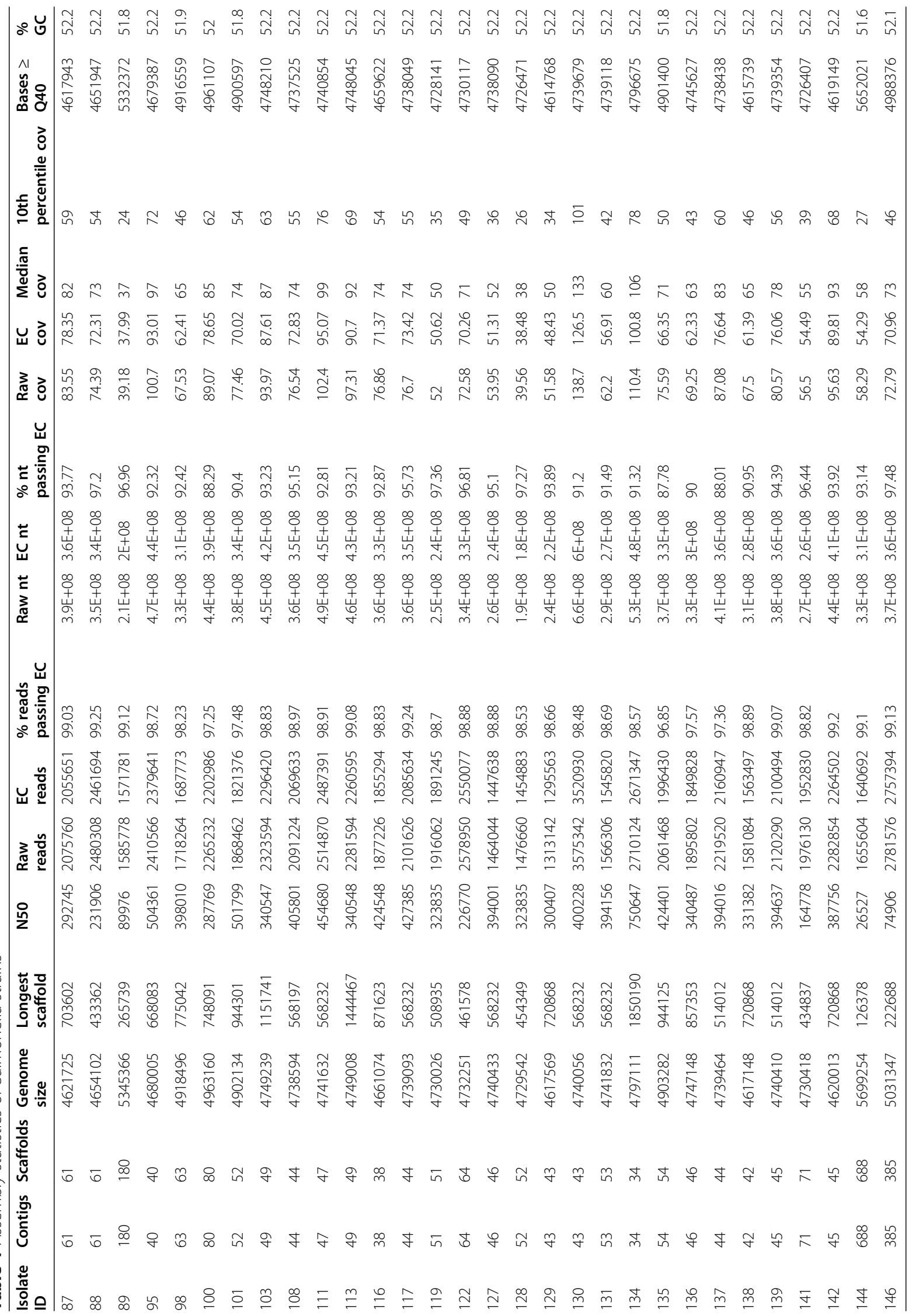


Table 2 Distribution of plasmid replicons and MLSTs of Salmonella from fish

\begin{tabular}{|c|c|c|c|c|c|c|}
\hline Sample ID & Serotype & Antimicrobial resistances genes & Plasmid replicon & MLST (ST) & ParC mutation & Accession numbers \\
\hline 87 & Nima & aac(6')-laa & 0 & 8086 & Thr57Ser & SAMN18249072 \\
\hline 88 & Tennessee & $\operatorname{aac}\left(6^{\prime}\right)-$ laa; fosA7 & 0 & 8395 & Thr57Ser & SAMN18249073 \\
\hline 89 & Teshie & aac(6')-laa & IncFIB, IncFII & 530 & - & SAMN18249074 \\
\hline 95 & Derby & aac(6')-laa & 0 & 7880 & Thr57Ser & SAMN18249075 \\
\hline 98 & | 39:z10:e,n,z15 & aac(6')-laa & 0 & 8401 & Thr57Ser & SAMN18249076 \\
\hline 100 & | 30:y:- & aac(6')-laa & 0 & 8397 & Thr57Ser & SAMN18249077 \\
\hline 101 & | 13:i:z6 & aac(6')-laa & 0 & 8396 & - & SAMN18249078 \\
\hline 103 & Liverpool & aac(6')-laa & Col(pHAD28), Col4401 & $1959^{a}$ & Thr57Ser & SAMN18249079 \\
\hline 108 & Tennessee & aac(6')-laa & 0 & 8398 & Thr57Ser & SAMN18249080 \\
\hline 111 & Tennessee & aac $\left(6^{\prime}\right)$-laa & 0 & 8398 & Thr57Ser & SAMN16842897 \\
\hline 113 & Liverpool & aac(6')-laa & Col(pHAD28), Col4401 & 1959 & Thr57Ser & SAMN18249081 \\
\hline 116 & Tennessee & $\operatorname{aac}\left(6^{\prime}\right)-$ laa; fosA7 & 0 & 8395 & Thr57Ser & SAMN18249082 \\
\hline 117 & Tennessee & aac(6')-laa & 0 & 8398 & Thr57Ser & SAMN18249083 \\
\hline 119 & Tennessee & aac(6')-laa & 0 & 8398 & Thr57Ser & SAMN18249084 \\
\hline 122 & Tennessee & $\operatorname{aac}\left(6^{\prime}\right)$-laa & 0 & 8398 & Thr57Ser & SAMN18249085 \\
\hline 127 & Tennessee & aac(6)-laa & 0 & 8398 & Thr57Ser & SAMN18249086 \\
\hline 128 & Tennessee & $\operatorname{aac}\left(6^{\prime}\right)-1 a a$ & 0 & 8398 & Thr57Ser & SAMN18249087 \\
\hline 129 & Nima & aac(6')-laa & 0 & 8086 & Thr57Ser & SAMN18249088 \\
\hline 130 & Tennessee & aac(6')-laa & 0 & 8398 & Thr57Ser & SAMN18249089 \\
\hline 131 & Tennessee & $\operatorname{aac}\left(6^{\prime}\right)$-laa & Col(MG828) & 8398 & Thr57Ser & SAMN18249090 \\
\hline 134 & Kokomlemle & aac(6')-laa & $\operatorname{lncFII(S)}$ & 2696 & Thr57Ser & SAMN18249091 \\
\hline 135 & | 13:i:z6 & $\operatorname{aac}\left(6^{\prime}\right)$-laa & 0 & 8396 & - & SAMN18249092 \\
\hline 136 & Liverpool & aac(6')-laa & Col(pHAD28), Col4401 & 1959 & Thr57Ser & SAMN18249093 \\
\hline 137 & Tennessee & aac(6')-laa & 0 & 8398 & Thr57Ser & SAMN18249094 \\
\hline 138 & Nima & aac(6')-laa & 0 & 8086 & Thr57Ser & SAMN18249095 \\
\hline 139 & Tennessee & $\operatorname{aac}\left(6^{\prime}\right)$-laa & 0 & 8398 & Thr57Ser & SAMN18249096 \\
\hline 141 & Tennessee & aac(6')-laa & 0 & 8398 & Thr57Ser & SAMN18249097 \\
\hline 142 & Nima & $\operatorname{aac}\left(6^{\prime}\right)$-laa & 0 & 8086 & Thr57Ser & SAMN18249098 \\
\hline 144 & | 39:f,g:e,n,z15 & aac(6')-laa & 0 & b Unknown & Thr57Ser & SAMN18249099 \\
\hline 146 & Tennessee & $\operatorname{aac}\left(6^{\prime}\right)-\operatorname{laa}$, fosA7 & 0 & c Unknown & Thr57Ser & SAMN16842913 \\
\hline
\end{tabular}

Less than $100 \%$ identity

${ }^{\text {b}}$ Nearest STs: 384, 696, 1859, 2320, 4924, 5805, 6540, 6730, 6732, 6734

'Nearest ST: 8398

possibility of cross-contamination due to a lack of training and information on the causes and consequences of foodborne diseases (Barro et al. 2007). The prevalence of Salmonella in fish in this study is higher than those reported by Broughton and Walker (2009), from fish in China (5\%) and by Heinitz et al. (2000) in U.S.-imported raw seafood from several Asian countries (10\%). These variations in prevalence can be explained by differences in farming methods, and in the food safety regulations of each country. For example, in Burkina Faso, many researchers demonstrated that good hygienic practices are not respected yet by food sellers and domestic food safety regulation and/or training programs are still missing (Barro et al. 2008; Kagambèga et al. 2011; Kagambèga et al. 2012).

Salmonella Tennessee was the most prevalent serotype among fish samples. This serotype of Salmonella was detected in different types of samples and in the stools of patients with diarrhea in other studies from Burkina Faso (Kagambèga et al. 2017). Salmonella Tennessee has also been implicated in outbreaks in the USA due to contaminated peanut butter, powdered milk products, and infant formula (Center for Disease Control and Prevention (CDC) 2007; Center for Disease Control and Prevention (CDC) 1993). These facts show us that the Tennessee serotype is not necessarily linked to a specific 
food or environment but can infect humans through many contaminated foods.

We also have the presence of $S$. Liverpool and $S$. Teshie, which are pathogenic serotype and have not been identified in our previous studies carried out in Burkina Faso in diarrheal patients, chickens, the environment, or animals (Kagambèga et al. 2017; Bonkoungou et al. 2013; Traoré et al. 2015). Salmonella Derby was identified as the most dominant in our previous studies in chickens and slaughter animals (Kagambèga et al. 2013). Salmonella Nima and S. Kokomlemle also have been isolated in chicken and beef previously in Burkina Faso (Kagambèga et al. 2013).

The presence of these serotypes in fish shows that chicken, slaughter animals, the environment, and humans share the same pathogens that circulate in our country.

Ten different MLST sequence types were found in this study, and two strains possessed Unknown ST. Two MSLT types were detected in our study with $S$. Tennessee. This may show that $S$. Tennessee has genetic diversity within its population. We can say that the other serotype with a unique MSLT type retained their genetic characteristic during their evolution while keeping the same type of MLST. On the other hand, $S$. Tennessee population structure has changed during evolution.

All the Salmonella strains found in this study possessed the aminoglycoside resistance gene encoding acetyltransferases, aac(6')-Iaa. While this gene was not functional in the present study and are commonly nonfunctional in Salmonella, mutations in the promoter of the gene can lead to expression and phenotypic resistance (Magnet et al. 1999). Rather et al. (1993) demonstrated that aminoglycoside resistance in Salmonella strains is usually secondary to increased gene expression following regulatory mutations.

The fosA7 gene conferring resistance to fosfomycin was detected in three antibiotic susceptible strains. Since this antibiotic was not tested in this study, we cannot conclude that this gene is functional or not. Rehman et al. (2017) demonstrated that the gene fosA7 is responsible for fosfomycin resistance.

Point mutations in the quinolone resistancedetermining regions (QRDRs) were detected in 27 (90\%) isolates at positions 57 (Thr57Ser), which can confer resistance to quinolones. However, all isolates were susceptible to both nalidixic acid and ciprofloxacin. Consistent with the results presented here, other Salmonella isolates containing this mutation also exhibited susceptibility to nalidixic acid or ciprofloxacin; thus, this mutation is thought to not confer resistance in all serotypes of Salmonella (Baucheron et al. 2005).

In this study, two Salmonella Kokomlemle and one $S$. Teshie possessed IncFII-type plasmids, which have been important in spreading resistance genes such as bla NDM-1 and bla CTX-M-15 (Xavier et al. 2016). Both strains did not harbor any beta-lactamase resistance genes. All the Salmonella Liverpool contained Col(pHAD28), Col4401, and one S. Tennessee possessed Col(MG828) plasmid types. These plasmid types have been associated with quinolone resistances in Salmonella strains (Fiegen et al. 2017). More investigation into these plasmid sequences are needed to determine any benefit they provide the strains.

\section{Conclusion}

This study has shown that widely consumed fish in Burkina Faso are contaminated with pathogenic bacteria of the genus Salmonella. The microbiological quality of fish sold in Burkina Faso must be improved to reduce the risks of contamination to consumers. Improved food safety will lead to reduced losses, better access to markets, and hence better incomes. The modern molecular biology technique used in this study, whole-genome sequencing, is a technique that is not yet available in the developing countries. An urgent action is needed by decision-makers in Burkina Faso, other developing countries, and countries around the world to collaborate in the regulation and monitoring of foodborne pathogens.

\section{Abbreviations}

WGS: Whole-genome sequencing; NTS: Non-typhoidal Salmonella; CDC: Centers for Disease Control and Prevention; MLST: Multilocus sequence typing; MDR: Multidrug resistant; LaBESTA: Laboratoire de Biologie Moléculaire, d'épidémiologie et de surveillance des bactéries et virus transmissible par les aliments; USA: United States of America

\section{Acknowledgements}

We thank the personnel and technicians from the Bacterial Epidemiology and Antimicrobial Resistance Research Unit, USDA, ARS, Athens, Georgia, USA, for the collaboration and help.

\section{Authors' contributions}

$A K, S B$, and SKD carried out the strain's isolation and characterization. $L H, A K$, SP, SKG, HR, and EAM carried out the WGS analysis, AK drafted the manuscript. EAM and LH participated in manuscript writing. NB, CRJ, and JGF supervised the WGS and participated in writing the manuscript. All authors read, commented on, and approved of the final manuscript.

\section{Funding}

This study was supported by the United States Fulbright scholarship grant to AK and the Bacterial Epidemiology and Antimicrobial Resistance Research Unit, USDA, ARS, Athens, Georgia, USA. The funding sources had no role in the design of the study and collection, analysis, and interpretation of data and in writing the manuscript.

\section{Availability of data and materials}

The whole-genome shotgun project has been deposited at GenBank under BioProject number PRJNA713376 (https://www.ncbi.nlm.nih.gov/bioproject/ PRJNA713376).

\section{Declarations}

Ethics approval and consent to participate Not applicable. 


\section{Consent for publication}

Not applicable.

\section{Competing interests}

The authors declare that they have no competing interests.

\section{Author details}

${ }^{1}$ Bacterial Epidemiology and Antimicrobial Resistance Research Unit, U.S. National Poultry Research Center, USDA, ARS, Athens, Georgia, USA. ${ }^{2}$ Laboratoire de Biologie Moléculaire, d'épidémiologie et de surveillance des bactéries et virus transmissibles par les aliments (LaBESTA)/Ecole Doctorale Sciences et Technologies (EDST), Université Joseph KI-ZERBO, Ouagadougou, Burkina Faso. ${ }^{3}$ Institut des Sciences, Ministère des enseignement supérieur, de la recherche scientifique et de l'innovation, Ouagadougou, Burkina Faso. ${ }^{4}$ Hygiene and Zoonoses Department, Faculty of Veterinary Medicine, Mansoura University, Mansoura 35516, Egypt.

Received: 17 March 2021 Accepted: 16 July 2021

Published online: 31 July 2021

\section{References}

Amagliani G, Brandi G, Schiavano GF (2012) Incidence and role of Salmonella in seafood safety. Food Res Int 45(2):780-788. https://doi.org/10.1016/j.foodres.2 011.06.022

Barrett KA, Nakao JH, Taylor E, Eggers C, Gould LH (2017) Fish-associated foodborne disease outbreaks: United States, 1998-2015. Foodborne Pathog Dis 14(9):537-543. https://doi.org/10.1089/fpd.2017.2286

Barro N, Gamene AA, Itsiembou Y, Savadogo A, Nikiema AP, Ouattara CAT, De Souza CA, Traoré AS (2007) Street-vended foods improvement: contamination mechanisms and application of food safety objective strategy: critical review. Pak J Nutr 6(1):1-10

Barro N, Tahita MC, Traore O, Sangare L, De Souza CA, Traore AS (2008) Risks associated with practices, processes, and environment of ready-to-eat and street-vended foods that lead to contamination by common foodborne viruses. In: Aderson PL, Lachan JP (eds) Hygiene and its role in health, pp 129-153

Baucheron S, Chaslus-Dancla E, Cloeckaert A, Chiu CH, Butaye P (2005) High-level resistance to fluoroquinolones linked to mutations in gyrA, parC, and parE in Salmonella enterica Serovar Schwarzengrund isolates from humans in Taiwan. J Antimicrob Agents Chemother 49(2):862-863. https://doi.org/1 0.1128/AAC.49.2.862-863.2005

Bonkoungou IJO, Haukka K, Österblad M, Hakanen AJ, Traoré AS, Barro N, Siitonen A (2013) Bacterial and viral etiology of childhood diarrhea in Ouagadougou, Burkina Faso. BMC Pediatr 13:36 http://www.biomedcentral com/1471-2431/13/36

Broughton El, Walker DG (2009) Prevalence of antibiotic-resistant Salmonella in fish in Guangdong, China. Foodborne Pathog Dis 6(4):519-521. https://doi. org/10.1089/fpd.2008.0196

Carattoli A, Zankari E, Garcia-Fernandez A, Voldby Larsen M, Lund O, Villa L, Aarestrup FM, Hasman H (2014) PlasmidFinder and pMLST: in silico detection and typing of plasmids using PlasmidFinder and Plasmid Multilocus Sequence Typing. Antimicrob Agents Chemother 58(7):3895-3903. https:// doi.org/10.1128/AAC.02412-14

Center for Disease Control and Prevention (CDC) (1993) Salmonella serotype Tennessee in powdered milk products and infant formula---Canada and the United States. Morb Mortal Wkly Rep 42:501-519

Center for Disease Control and Prevention (CDC) (2007) Multistate outbreak of Salmonella serotype Tennessee infections associated with peanut butter -United States, 2006-2007. Morb Mortal Wkly Rep 56:521-524

Center for Disease Control and Prevention (CDC). Antibiotic resistance: a global threat. 2019. https://www.cdc.gov/features/antibiotic-resistance-global/index. html

Clinical and Laboratory Standards Institute (CLSI) (2016) Performance standards for antimicrobial susceptibility testing. In: CLSI Supplement M100S, 26th edn. CLSI, Wayne

Coil D, Jospin G, Darling AE (2015) A5-miseq: an updated pipeline to assemble microbial genomes from Illumina MiSeq data. Bioinformatics. 31(4):587-589. https://doi.org/10.1093/bioinformatics/btu661

Fiegen U, Klein G, De Jong A, Kehrenberg C (2017) Detection of a novel qnrB19carrying plasmid variant mediating decreased fluoroquinolone susceptibility in Salmonella enterica Serovar Hadar. J Microb Drug Resist 23(3):280-284 https://doi.org/10.1089/mdr.2016.0067

Gonzalez-Escalona N, Cachicas V, Acevedo C, Rioseco ML, Vergara JA, Cabello F, Romero J, Espejo RT (2005) Vibrio parahaemolyticus diarrhea, Chile, 1998 and 2004. Emerg Infect Dis 11(1):129-131. https://doi.org/10.3201/eid1101.040762

Heinitz ML, Ruble RD, Wagner DE, Tatini SR (2000) Incidence of Salmonella in fish and seafood. J Food Prot 63(5):579-592. https://doi.org/10.4315/0362-028X63.5.579

International Organization for Standardization (ISO) 6579-1. Microbiology of the food chain - horizontal method for the detection, enumeration and serotyping of Salmonella. Part 1: Detection of Salmonella spp. 2017.

Issenhuth-Jeanjean S, Roggentin P, Mikoleit M, Guibourdenche M, Pinna E, Nair S, Fields IP, Weill FX (2014) Supplement 2008-2010 (no. 48) to the WhiteKauffmann-Le Minor scheme. Res Microbiol 7(65):526-530. https://doi.org/1 0.1016/j.resmic.2014.07.004

Kagambèga A, Barro N, Traoré AS, Siitonen A, Haukka K (2012) Characterization of Salmonella enterica and detection of the virulence genes specific to diarrheagenic Escherichia coli from poultry carcasses in Ouagadougou, Burkina Faso. Foodborne Pathog Dis 9(7):589-593. https://doi.org/10.1089/fpd.2011.1071

Kagambèga A, Bouda SC, Bako E, Cissé H, Barro N, Haukka K (2017) Diversity and antimicrobial resistance of Salmonella strains isolated from different sources in Burkina Faso. Afr J Microbiol Res 11(40):1495-1504. https://doi.org/10. 5897/AJMR2017.8698

Kagambèga A, Haukka K, Siitonen A, Traoré AS, Barro N (2011) Prevalence of Salmonella enterica and the hygienic indicator Escherichia coli in raw meat at markets in Ouagadougou, Burkina Faso. J Food Prot 74(9):1547-1551. https:// doi.org/10.4315/0362-028X.JFP-11-124

Kagambèga A, Lienemann T, Aulu L, Traoré AS, Barro N, Siitonen A, Haukka K (2013) Prevalence and characterization of Salmonella enterica from the intestines of cattle, poultry, swine and hedgehogs in Burkina Faso and their comparison to human Salmonella isolate. Salmonella BMC Microbiol 13(1): 253. https://doi.org/10.1186/1471-2180-13-253

Kris-Etherton PM, Harris WS, Appel $\sqcup$ (2002) Fish consumption, fish oil, omega-3 fatty acids, and cardiovascular disease: AHA scientific statement. Circulation. 106(21):2747-2757. https://doi.org/10.1161/01.CIR.0000038493.65177.94

Larsen MV, Cosentino S, Rasmussen S, Friis C, Hasman H, Marvig RL, Jelsbak L, Sicheritz-Pontén T, Ussery DW, Aarestrup FM, Lund O (2012) Multilocus sequence typing of total genome sequenced bacteria. J Clin Micobiol 52(5): $1501-1510$

Magnet S, Courvalin P, Lambert T (1999) Activation of the Cryptic aac(6')lyAminoglycoside resistance gene of Salmonella by a chromosomal deletion generating a transcriptional fusion. J Bacteriol 181(21):6650-6655. https://doi. org/10.1128/JB.181.21.6650-6655.1999

Ministry of economic and sustainable development (2015). Annuaire des Statistiques douanières, Burkina Faso. http://cns.bf/IMG/pdf/annuaire_sta tistiques_douanieres_2015.pdf

Miranda CD, Godoy FA, Lee MR (2018) Current status of the use of antibiotics, and the antimicrobial resistance in the Chilean salmon farms. Front Microbiol 9:1284. https://doi.org/10.3389/fmicb.2018.01284

Nwiyi P, Onyeabor A (2012) Occurrence of Salmonella spp. from fresh fish (Tilapia nilotica Linn) using improved isolation methods. J Anim Feed Res 2(6):475478

Rather PN, Orosz E, Hare RS, Miller G, Shaw KJ (1993) Characterization and transcriptional regulation of the 29-N-acetyltransferase gene of Providencia stuartii. J Bacteriol 175(20):6492-6498. https://doi.org/10.1128/jb.175.20.64926498.1993

Rehman MA, Yin X, PersaudLachhman MG, Diarra MS (2017) First detection of a fosfomycin resistance gene, fosA7, in Salmonella enterica serovar Heidelberg isolated from broiler chickens. J Antimicrob Agents Chemother 61:e00410e00417. https://doi.org/10.1128/AAC.00410-17.44

Sørum H (2006). Antimicrobial Resistance in Bacteria of Animal Origin. In: Antimicrobial drug resistance in fish pathogens. Chapter 13 (Aarestrup, F.M. Ed.). American Society for Microbiology Press, Washington, DC. pp. 213-238.

Tatusova T, DiCuccio M, Badretdin A, Chetvernin V, Nawrocki EP, Zaslavsky L, Lomsadze A, Pruitt KD, Borodovsky M, Ostell J (2016) NCBI prokaryotic genome annotation pipeline. Nucleic Acids Res 44(14):6614-6624. https://doi. org/10.1093/nar/gkw569

Traoré O, Nyholm O, Siitonen A, Bonkoungou IJO, Traoré AS, Barro N, Haukka K (2015) Prevalence and diversity of Salmonella enterica in water, fish and lettuce in Ouagadougou, Burkina Faso. BMC Microbiol 15(1):151. https://doi. org/10.1186/s12866-015-0484-7 
World Health Organization (WHO). Estimates of the global burden of foodborne diseases. 2015. http://www.who.int/foodsafety/areas_work/foodborne-disea ses/ferg/en/

Xavier BB, Lammens C, Butaye P, Goossens H, Malhotra-Kumar S (2016) Complete sequence of an IncFll plasmid harbouring the colistin resistance gene mcr-1 isolated from Belgian pig farms. J Antimicrob Agents Chemother 71(8):23422323. https://doi.org/10.1093/jac/dkw191

Yan H, Li L, Alam MJ, Shinoda S, Miyoshi S, Shi L (2010) Prevalence and antimicrobial resistance of Salmonella in retail foods in northern China. Int J Food Microbiol 143(3):230-234. https://doi.org/10.1016/j.jifoodmicro.2010.07 034

Zankari E, Hasman H, Cosentino S, Vestergaard M, Rasmussen S, Lund O, Aarestrup FM, Larsen MV (2012) Identification of acquired antimicrobial resistance genes. J Antimicrob Chemother 67(11):2640-2644. https://doi. org/10.1093/jac/dks261

\section{Publisher's Note}

Springer Nature remains neutral with regard to jurisdictional claims in published maps and institutional affiliations.

Ready to submit your research? Choose BMC and benefit from:

- fast, convenient online submission

- thorough peer review by experienced researchers in your field

- rapid publication on acceptance

- support for research data, including large and complex data types

- gold Open Access which fosters wider collaboration and increased citations

- maximum visibility for your research: over $100 \mathrm{M}$ website views per year

At BMC, research is always in progress.

Learn more biomedcentral.com/submissions 